DOI: 10.46340/eppd.2020.7.3.18

Mykola Polovyi, ScD in Political Science

ORCID ID: https://orcid.org/0000-0001-7283-3528

Vasyl' Stus Donetsk National University, Ukraine

Alina Polukhina, PhD in Political Science

ORCID ID: https://orcid.org/0000-0002-3475-448X

\title{
LOCAL DEMOCRACY AS AN IMPORTANT DETERMINANT OF THE MUNICIPAL REFORM IN UKRAINE: PROBLEM ASPECTS
}

\author{
Микола Польовий, д. політ. н. \\ Донецький національний університет імені Василя Стуса, Україна \\ Аліна Полухіна, к. політ. н.

\section{ЛОКАЛЬНА ДЕМОКРАТІЯ ЯК ВАЖЛИВА ДЕТЕРМІНАНТА МУНІЦИПАЛЬНОЇ РЕФОРМИ В УКРАЇНІ: ПРОБЛЕМНІ АСПЕКТИ}

\begin{abstract}
The article considers the role of local democracy in the organization of governance at all territorial levels and its role in addressing important issues in the interests of residents of territorial communities. The main problems of the municipal reform in Ukraine have also been identified. Differences in the definitions of competence and purpose of local self-government institutions are outlined. The main problem aspects of local democracy are determined, which are the ratio between the autonomy of society and universal democratic norms operating in a single national environment; institutionalization of local democracy.

Keywords: democracy, local democracy, institutions of local democracy, local self-government, municipal reform.
\end{abstract}

Особливого значення набувають сучасні тренди децентралізації політичної системи України, тому у процесі реформування муніципальної політики підвищується роль локальної демократії в організації управління на всіх територіальних рівнях та для вирішення важливих питань в інтересах жителів територіальних громад. Одним із завдань муніципальної реформи в Україні $€$ «створення самодостатніх та дієздатних територіальних громад, але це неможливо сьогодні без розвитку локальної демократії» ${ }^{1}$.

Актуальність дослідження локальної демократії як важливої детермінанти муніципальної реформи обумовлена необхідністю більш глибокого осмислення понять, ознак, інститутів, умов і факторів, які визначають зміст і суть локальної демократії. Локальна демократія - поняття, що пов'язане $з$ поняттями «демократія», «місцеве самоврядування» ${ }^{2}$. Адже локальна демократія дуже змістовне явище, що пов'язане безпосередньо з місцевим самоврядуванням. Теоретичне дослідження локальної демократії, неможливо уявити у відриві від місцевого самоврядування. Дані поняття тісно переплітаються один з одним, але не зовсім тотожні. Демократія виступає способом реалізації політичної влади, в тому числі і за допомогою самоврядування ${ }^{3}$. У свою чергу,

\footnotetext{
${ }^{1}$ Ковбасюк, Ю.В. (ред.) (2014). Місиеве самоврядування в Украйні: сучасний стан та основні напрями модернізації: наукова доповідь. Київ: НАДУ, 94.

${ }^{2}$ Федоринов, Е.В., Вонсович, С.Г. (2013). Концепт локальной демократии в транзитологической парадигме. Вестник ВГУ. Серия: История. Политология. Социология, 2, 73.

${ }^{3}$ Крамаренко, С.В. (2013). Развитие институтов непосредственной демократии в местном самоуправлении: теоретико-правовые и прикладные аспекты: Воронеж.
} 
демократичність політичного режиму в суспільстві може визначатися впровадженням в його життя принципів місцевого самоврядування.

Поширення цінностей локальної демократії сприяє залученню громадян до реалізації державної влади, реалізує право на політичну участь громадян, а значить, сприяє консолідації демократії. Головною проблемою перехідних суспільств, в тому числі в Україні- проблема розподілу компетенції державної влади та самоврядування, вимоги до збільшення автономії територіальних одиниць, реалізація на практиці принципу субсидіарності.

Локальна демократія визначається як: національна модель демократії; участь громадян в управлінні; форма самоорганізації громадян; демократичний устрій на муніципальному рівні ${ }^{1}$. До ознак локальної демократії належать ${ }^{2}$ місцеве самоврядування виступає в ролі колективного суб'єкта, яке управляє безпосередньо власним життям шляхом самостійного вирішення питань місцевого значення; особливість суспільних відносин, в рамках яких здійснюється демократія. Локальна демократія існує лише в рамках особливого виду суспільних відносин, які складаються в рамках вирішення питань місцевого значення конкретного муніципального утворення; використання демократичних форм управління справами місцевої громади. Рішення питань місцевого значення здійснюється за допомогою системи органів місцевого самоврядування, які наділені владними повноваженнями легітимним способом, однак, рішення даних питань може бути здійснено територіальною громадою i безпосередньо, якщо для цього існуватиме нагальна необхідність; врахування упроцесі управління історичних та інших місцевих традицій. Нормативно-правове регулювання в сучасній Україні дозволяє використовувати різні моделі не лише місцевого самоврядування, але і різні види локальної демократії при вирішенні питань місцевого значення. Дана специфіка пояснюється великою територією нашої країни і наявністю різних етнічних спільнот, в тому числі і в межах однієї територіальної громади.

Таким чином, законодавство дозволяє територіальній громаді самій вибрати прийнятну модель місцевого самоврядування, яка повною мірою відповідатиме місцевим потребам; можливість здійснення контролю під час вирішення питань місцевого значення органами і посадовими особами місцевого самоврядування. Даний рівень влади, як найбільш наближений до населення, дозволяє більш ефективно застосовувати методи контролю над виконанням делегованих повноважень органам місцевого самоврядування.

Локальна демократія включає в себе наступні інститути: місцеві вибори; референдуми та інші форми прямої демократії на місцевому рівні; дорадчі структури при місцевих органах влади; публічні слухання; форми самоорганізації (організації за інтересами, територіальні організації); способи вираження інтересів громадян, включаючи місцеві кампанії із захисту своїх прав, і т. д.

Локальну демократію розуміють як один із способів організації місцевого самоврядування, при якому: територіальна спільнота наділена автономією для задоволення власних інтересів; спирається на демократичні цінності, використовуючи демократичні механізми, залучає до прийняття рішень членів спільноти; реально використовує інструменти прямої демократії으, та, яка характеризується наявністю факторів, що сприяють становленню локальної демократії: нормативні та політичні. До нормативних ми можемо віднести історичні традиції та зразки політичної поведінки, норми права; до політичних - політична участь громадян, реалізація принципу виборності органів місцевого самоврядування, розподіл повноважень між державною владою і самоврядуванням, відносини між представницькими і виконавчими органами місцевого самоврядування.

Метою даної статті є аналіз основних проблемних аспектів локальної демократії як основної детермінанти муніципальної реформи в Україні.

Для ефективної реалізації муніципальної реформи вкрай важливою є розбудова інститутів локальної демократії, адже як влучно відзначає К. Буря: «на сучасному етапі локальна демократія $\epsilon$ не лише засобом репрезентації локальних інтересів, але й одним із потужних системотворчих

\footnotetext{
${ }^{1}$ Голосов, Г. (2010). Локальная демократия. Санкт-Петербург, 5.

${ }^{2}$ Шипулин, Н.С. К вопросу о понятии «муниципальная демократия». $<$ https://pgu.ru/upload/iblock/c76/

Pages-from-CH- -18 80-ekz. 8.pdf $>$.

${ }^{3}$ Федоринов, Е.В., Вонсович, С.Г. (2013). Концепт локальной демократии в транзитологической парадигме.

Вестник ВГУ. Серия: История. Политология. Соииология, 2, 75.
} 
чинників для демократичних політичних систем» ${ }^{1}$. Варто відзначити, що у сучасній Україні становлення локальної демократії та децентралізація лише почались, і вагомого значення для здійснення муніципальної політики набувають: інституалізація місцевих громад, вироблення механізмів політичної взаємодії всередині представницьких органів влади та послідовна реалізація муніципальної реформи.

До загальних проблемних аспектів локальної демократії належать: співвідношення автономності суспільства i універсальних демократичних норм, що діють в єдиному загальнонаціональному середовищі ${ }^{2}$; інституціоналізація локальної демократії; цей процес передбачає дифузію влади, що не влаштовує політиків національного рівня ${ }^{3}$. До нагальних проблемних питань, що потребують вирішення, слід віднести також: визначення територіальної основи для діяльності органів місцевого самоврядування та органів виконавчої влади, що здатні забезпечити доступність і належну якість публічних послуг, що надаються такими органами, а також необхідної для цього ресурсної бази; створення належних матеріальних, фінансових та організаційних умов для забезпечення здійснення органами місцевого самоврядування власних i делегованих повноважень; розмежування повноважень у системі органів місцевого самоврядування та органів виконавчої влади на різних рівнях адміністративно-територіального устрою за принципом субсидіарності, а також між органами виконавчої влади та органами місцевого самоврядування на засадах децентралізації влади; запровадження механізму державного контролю за відповідністю Конституції та законам України рішень органів місцевого самоврядування і якістю надання населенню публічних послуг та ін. ${ }^{4}$ Також до основних проблем реалізації муніципальної реформи слід віднести: невідповідність функцій територіальних громад як суб’єкта місцевого самоврядування реальному дифузійному стану вітчизняних громад, які являють собою неконсолідовану сукупність мешканців. На нашу думку, формування локальних демократичних політичних інститутів дозволить поступово забезпечити нову якість ухвалення політичних рішень $\mathrm{i}$ розвитку територіальних громад, і саме громадянське суспільство виступає основною компонентою реформ локальної демократії.

Якщо розглядати феномен локальної демократії крізь нормативно-правову призму, то слід виокремити наступні проблеми реалізації муніципальної реформи в Україні: відсутність гарантій для реалізації повноважень економічної основи діяльності визнаних і зареєстрованих державою територіальних громад; відсутність достатнього фінансування та нечіткість формулювання повноважень ${ }^{5}$ (важливою залишається процедура розподілу фінансової допомоги між громадами та місцевими радами, які продовжують існувати: не вирішено питання їх взаємовідносин у фінансовій сфері, не розроблено механізми оптимального розподілу субвенцій між громадами згідно їх розмірами (чисельності населення, площі), виділення фінансової допомоги новоствореним громадам для їх вбудовування в новий територіальний устрій, яке пов'язане з додатковими витратами в освітній, медичній, транспортній та інших сферах); ігнорування регіональної специфіки, сформованої під впливом історичних, релігійних, етнічних, мовних, економічних, інституційних, ціннісних, геополітичних орієнтацій та інших особливостей ${ }^{6}$. Це і повільне прийняття поправок до чинного законодавства (в тому числі до Конституції), і неврегульованість адміністративних компетенцій i процедур взаємодії між старими (державними адміністраціями) та новими (громадами) органами влади на місцях, а також невирішені проблеми оптимальної структури органів місцевого самоврядування, функціонування виборчої системи та ін. Однак, слід відзначити, що локальні нормативно-правові акти створюють низку перепон, що перешкоджають територіальним громадам проводити збори громадян за місцем проживання (залежність від рішення

\footnotetext{
${ }^{1}$ Буря, К. (2017). Локальна демократія: специфіка трансформації у період посткомунізму. Вісник Львівського університету. Серія філософсько-політологічні студї, 14, 110. 110-117.

${ }^{2}$ Whalen, H. (1960). Ideology, Democracy and the Foundations of Local Self-Government. The Canadian Journal of Economics and Political Science, 26, 3, 377-395.

${ }^{3}$ Campbell, A., Coulson, A. (2006). Into the Mainstream: local Democracy in Central and Eastern Europe. Local Government Studies, 32, 5, 543-561.

${ }^{4}$ Ковбасюк, Ю.В. (ред.) (2014). Місцеве самоврядування в Украӥні: сучасний стан та основні напрями модернізаиії: наукова доповідь. Київ: НАДУ, 4.

${ }^{5}$ Олуйко, В. (2002). Муніципальна реформа: на часі кроки вперед. Урядовий кур'єр.

${ }^{6}$ Воротін, В.С. (ред.) (2010). Державне управління регіональним розвитком Украӥни: монографія. Київ: НІСД.
} 
міського голови або місцевої ради; встановлення кількісних вимог щодо членів ініціативної групи громадян або кількості громадян, з ініціативи яких можуть скликатися загальні збори; наявність складної процедури скликання зборів громадян за місцем проживання з ініціативи членів громади та інститутів громадянського суспільства ${ }^{1}$ ). Основною формою локальної демократії можуть бути місцеві ініціативи. Як форма волевиявлення членів територіальної громади вони включають ініціювання розгляду сільською, селищною, міською радою будь-якого питання місцевого значення.

Важливою детермінантою, що стримує процес формування локальної демократії є розбіжності у визначеннях компетенції та призначення інститутів місцевого самоврядування, а також непрозорість влади, корупція, залежність засобів масової інформації, складність доступу громадян до вичерпної, всебічної та об'єктивної інформації і т.д. Цю проблему досліджував, зокрема, Баймуратов М.М., який, вказуючи на суперечливість різних доктринальних позицій, зазначив: «...представники конституційної і муніципальної доктрин, а також законодавець на даний час розглядають місцеве самоврядування в якості: одного з фундаментальних принципів конституційного ладу; однієї з форм народовладдя; специфічної підсистеми публічної влади; форми залучення громадян до участі в вирішенні питань місцевого значення; власне права на місцеве самоврядування; різновиду суспільного управління; інституту громадянського суспільства; фундаменту сучасної філософії прав людини; найважливішого соціально-політичного і соціально правового феномену; важливого конституюючого і інституційного чинника правової державності; суб'єкта міжнародних відносин; соціального і територіального простору, де продукуються системні локальні інтереси; соціального простору, де виникають, виявляються, формуються і реалізуються практично всі життєві устремління людини; сфери виникнення і прояву муніципальних прав i свобод людини; сфери реалізації компетенції місцевого самоврядування, його органів, посадових осіб, прав і обов'язків його суб'єктів; сфери реалізації практично всієї системи прав і свобод людини i громадянина; сфери реалізації функцій місцевого самоврядування; сфери реалізації відповідальності суб'єктів місцевого самоврядування тощо»².

Сучасний досвід запровадження локальної демократії не забезпечує територіальним громадам вирішальної ролі уздійснення та реалізації муніципальної політики. До причин слабкості громадських ініціатив на місцевому рівні належать: соціальна інертність організацій громадянського суспільства; недосконалість правового забезпечення реалізації громадських ініціатив на місцевому рівні; відсутність розуміння керівництва міських рад залучати представників громадськості до співуправління та прийняття рішень, що безпосередньо стосуються громадян ${ }^{3}$. Слабкість громадських ініціатив на місцевому рівні, на думку Т. С. Майко, має такі причини": соціальна інертність організацій громадянського суспільства; недосконалість правового забезпечення реалізації громадських ініціатив на місцевому рівні; небажання місцевих рад приймати 3 громадськістю спільні рішення.

Проведений аналіз свідчить про те, що муніципальне реформування є процесом досить неоднозначним. Це проявляється у відображенні інститутів місцевого самоврядування в правових нормах, неоднакової ролі публічно-владних відносин. Локальна демократія як основна детермінанта муніципальної реформи демонструє важливість публічної муніципальної влади у формуванні і функціонуванні демократичної правової державності та зростання такої ролі в процесі муніципальної реформи. Отже, муніципальна реформа в контексті іï зв'язку і прояву локальної демократії детермінує, об'єктивує та актуалізує проблематику формування та інтенсивного розвитку механізмів такої демократії як, насамперед, запоруки існування, функціонування, розвитку і вдосконалення самого інституту місцевого самоврядування, а також як формування в межах місцевого самоврядування соціального та нормативного простору, в якому виникають, формуються, реалізуються, гарантуються, охороняються, захищаються, інституціоналізуються права людини і громадянина.

\footnotetext{
${ }^{1}$ Місиева демократія в Украӥні: нові стандарти (2013). Київ: Агентство «Україна», 55-58.

2 Баймуратов, М.М. (2008). Місцеве самоврядування як суб’єкт компетенції: до визначення парадигми повнважень.

Порівняльно-правові дослідження, 2, 120.

${ }^{3}$ Пеліванова,Н. Механізми удосконалення реалізації громадських ініціатив.

$<$ old.niss.gov.ua/monitor/november08/7.htm>.

${ }^{4}$ Майко, Т.С. (2017). Міська рада як інститут локальної демократї в Україні: дисертація кандидата політичних наук. Луцьк, 181.
} 
Вважаємо, що для більш дієвого реформування муніципальної влади та вирішення вищевикладених проблем слід: підвищувати рівень обізнаності та навичок мерів і місцевих радників щодо передового досвіду в сфері локальної демократії та європейських стандартів місцевого самоврядування з метою реалізації принципів Європейської хартії місцевого самоврядування; підвищувати спроможність місцевих виборних представників керувати змінами на місцевому рівні; створити спільні узгоджені механізми та процеси, що сприяють ефективній координації та співпраці між різними рівнями місцевого самоврядування, національними асоціаціями та центральними органами влади для ефективного здійснення реформ; брати активнішу участь молодих лідерів в місцевій політиці і місцевих виборах, з кращим розумінням ролі місцевої влади і європейських стандартів місцевого самоврядування; реалізовувати місцеві ініціативи щодо участі громадян, підзвітності та прозорості, а також поширення результатів. На думку М. І. Цумарєва, з якою власне погоджуємось, у контексті розвитку локальної демократії необхідно забезпечити безперервний процес первинної локально-демократичної соціалізації молоді шляхом впровадження відповідних навчальних дисциплін в закладах вищої освіти ${ }^{1}$. На нашу думку, у даній програмі навчальної дисципліни необхідно більше уваги приділити тематиці механізмів локальної демократії та особливостям участі територіальних громад у їх реалізації. Адже це стане логічним продовженням набуття молоддю знань у сфері локальної демократії, сформує розуміння і навички важливості залученості громадян до політичного процесу на місцевому рівні, взаємодії 3 політичною реальністю та в подальшому.

В рамках подальших досліджень, для вирішення та розробки рекомендацій щодо реалізації муніципальної реформи в Україні, вважаємо доцільним розглянути загальновизнані європейські принципи та моделі локальної демократії країн $Є С$, що провели муніципальну реформу як частину загальної модернізації держави i суспільства, побудували національні моделі місцевого самоврядування, що мають загальну найважливішу ознаку- децентралізація публічної влади і перерозподіл юридичних повноважень і матеріально-технічних, фінансових та організаційних можливостей на рівень органів місцевого самоврядування.

\section{References:}

1. Baimuratov, M.M. (2008). Mistseve samovriaduvannia yak subiekt kompetentsii: do vyznachennia paradyhmy povnvazhen [Local self-government as a subject of competence: to determine the paradigm of authority]. Porivnialno-pravovi doslidzhennia [Comparative legal research], 2, 120. [in Ukrainian].

2. Buria, K. (2017). Lokalna demokratiia: spetsyfika transformatsii u period postkomunizmu [Local democracy: the specifics of transformation in the post-communist period]. Visnyk Lvivskoho universytetu. Seriia filosofskopolitolohichni studii [Bulletin of Lviv University. A series of philosophical and political studies], 14, 110-117. [in Ukrainian].

3. Vorotin, V.I. (ed.) (2010). Derzhavne upravlinnia rehionalnym rozvytkom Ukrainy: monohrafiia [State management of regional development of Ukraine: monograph]. Kyiv: NISD. [in Ukrainian].

4. Golosov, G. (2010). Lokal'naja demokratija [Local democracy]. Saint Petersburg. [in Russian].

5. Kramarenko, S.V. (2013). Razvitie institutov neposredstvennoj demokratii v mestnom samoupravlenii: teoretiko-pravovye i prikladnye aspekty [The development of direct democracy institutions in local government: legal and applied aspects]. Voronezh. [in Russian].

6. Kovbasiuk, Yu.V. (ed.) (2014). Mistseve samovriaduvannia v Ukraini: suchasnyi stan ta osnovni napriamy modernizatsii: naukova dopovid [Local self-government in Ukraine: current state and main directions of modernization: scientific report]. Kyiv: NADU. [in Ukrainian].

7. Maiko, T.S. (2017). Miska rada yak instytut lokalnoi demokratii v Ukraini: dysertatsiia kandydata politychnykh nauk [City Council as an institution of local democracy in Ukraine: Candidate Thesis of Political Sciences]. Lutsk. [in Ukrainian].

8. Mistseva demokratiia v Ukraini: novi standarty [Local democracy in Ukraine: new standards] (2013). Kyiv: Ukraina. [in Ukrainian].

9. Oluiko, V. (2002). Munitsypalna reforma: na chasi kroky vpered [Municipal reform: steps forward in time]. Uriadovyi kurier [Government courier]. [in Ukrainian].

10. Pelivanova, N. Mekhanizmy udoskonalennia realizatsii hromadskykh initsiatyv [Mechanisms for improving the implementation of public initiatives]. <old.niss.gov.ua/monitor/november08/7.htm>. [in Ukrainian].

\footnotetext{
${ }^{1}$ Цумарєв, М.І. (2019). Формування громадянської культури локальної демократії в сучасній Україні: дисертація кандидата політичних наук. Київ, 180.
} 
11. Fedorinov, E.V., Vonsovich, S.G. (2013). Koncept lokal’noj demokratii v tranzitologicheskoj paradigme [The concept of local democracy in a transitological paradigm]. Vestnik VGU. Serija: Istorija. Politologija. Sociologija [Bulletin of the Voronezh State University. Series: History. Political science. Sociology], 2, 73-80. [in Russian].

12. Tsumariev, M.I. (2019). Formuvannia hromadianskoi kultury lokalnoi demokratii v suchasnii Ukraini: dysertatsiia kandydata politychnykh nauk [Formation of civic culture of local democracy in modern Ukraine: Candidate Thesis of Political Sciences]. Kyiv. [in Ukrainian].

13. Shipulin, N.S. K voprosu o ponjatii «municipal'naja demokratija» [On the concept of “municipal democracy"]. $<$ https://pgu.ru/upload/iblock/c76/Pages-from-CH-_-18_80-ekz._8.pdf>. [in Russian].

14. Campbell, A., Coulson, A. (2006). Into the Mainstream: local Democracy in Central and Eastern Europe. Local Government Studies, 32, 5, 543-561. [in English].

15. Whalen, H. (1960). Ideology, Democracy and the Foundations of Local Self-Government. The Canadian Journal of Economics and Political Science, 26, 3, 377-395. [in English]. 